\title{
Patterns in seismology and palaeoseismology, and their application in long-term hazard assessments - the Swedish case in view of nuclear waste management
}

\author{
N.-A. Mörner \\ Paleogeophysics \& Geodynamics, Rösundavägen 17, 13336 Saltsjöbaden, Sweden \\ Correspondence to: N.-A. Mörner (morner@pog.nu)
}

Received: 12 May 2013 - Accepted: 1 July 2013 - Published: 24 July 2013

\begin{abstract}
Seismic events are recorded by instruments, historical notes and observational criteria in geology and archaeology. Those records form a pattern of events. From these patterns, we may assess the future seismic hazard. The time window of a recorded pattern and its completeness set the frames of the assessments. Whilst instrumental records in seismology only cover decades up to a century, archaeoseismology covers thousands of years and palaeoseismology tens of thousands of years. In Sweden, covered by ice during the Last Ice Age, the palaeoseismic data cover some $13000 \mathrm{yr}$. The nuclear industries in Sweden and Finland claim that the high-level nuclear waste can be buried in the bedrock under full safety for, at least, $100000 \mathrm{yr}$. It seems hard, if on the whole possible, to make such assessments from the short periods of pattern recognition in seismology $(<100 \mathrm{yr})$ and palaeoseismology $(\sim 13000 \mathrm{yr})$. All assessments seem to become meaningless, maybe even misleading. In this situation, we must restrict ourselves from making too optimistic an assessment. As some sort of minimum level of the seismic hazard, one may multiply the recorded seismic hazard over the past $10000 \mathrm{yr}$ by 10 , in order to cover the required minimum time of isolation of the toxic waste from the biosphere of $100000 \mathrm{yr}$.
\end{abstract}

\section{Introduction}

In China, we have a historical documentation of seismic events for the last $4250 \mathrm{yr}$ (Wang, 1987; Mörner, 1989). This is, of course, quite unique. In most other areas, we have fragments recorded over a few hundred years, or so. The recording by permanent instruments (seismographs) began at the end of the 19th century. This means that instrumental records are limited to the last half-century to the last century.

The seismic destruction of monuments (i.e. archaeoseismology) goes back a few thousands of years (e.g. Sintubin, 2011; Stiros and Jones, 1996). Sometimes, mythology may provide information of past seismic events (Piccardi and Masse, 2007).

Palaeoseismology (or earthquake geology) refers to seismic effects as recorded in geology (McCalpin, 2009; Mörner, 2003; Reicherter et al., 2009; Silva et al., 2011). This implies that the records may date to any part of the geological time. With respect to seismic hazard assessment, we must, how- ever, focus on the continual records of the Late Quaternary, especially the Holocene (e.g. Rockwell, 2010).

When we make seismic hazard assessments, there must be some sort of relation between the time frame of observation and the time frame of extrapolation. Seismology is good for assessment of the hazard of the near future - i.e. decades up to a century. When we are forced to make assessments for a longer time period, we have to rely on palaeoseismology (Fig. 1).

In the case of nuclear waste handling, the time span needed to be covered by seismic hazard assessment increases to the immense period of $100000 \mathrm{yr}$ or more (Mörner, 2012a). The question is whether we, by this, have not extended our predictions "in absurdum" (Mörner, 2001). The present paper will address this question.

IAEA (2010) has tried to establish criteria and recommendations for seismic hazard assessment in association with nuclear power installations. The focus is on the installation 


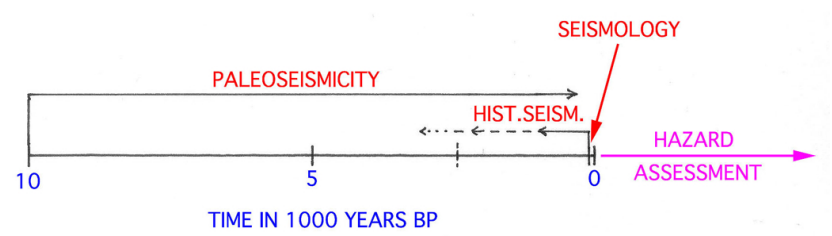

Figure 1. Means of recording seismic events over past and present time (from Mörner, 2011). For meaningful seismic hazard assessments, the seismic records must be combined with palaeoseismic analyses. Meaningful long-term predictions must be based on palaeoseismic data of high quality and completeness.

of nuclear power plants. It seems relevant that they firmly state that the assessment must be based on "the use to the greatest possible extent of the information collected" ("available", I would add, in this case, when the nuclear power industries take the liberty to discriminate among available observational facts), and "in accordance with the nature and complexity of the seismotectonic environment" (in this case Fennoscandia). Furthermore, they state the following:

The size of the relevant region may vary, depending on the geological and tectonic setting, and its shape may be asymmetric in order to include distant significant seismic sources of earthquakes. Its radial extent is typically $300 \mathrm{~km}$. In intra-plate regions, and in the particular case of investigations into the potential for tsunamis, the investigations may need to consider seismic sources at very great distances from the site.

\section{Results and records}

In this paper we will address the situation in Sweden, because it is in Sweden and Finland (and only in those two countries) where the nuclear industry has claimed that they have a method of final deposition of the high-level waste in the bedrock that will stay intact for "at least, 100000 years" (as claimed in Sweden) or "for 1 million years" (as claimed in Finland).

This calls for seismic hazard assessments. Because of the immense time period, we cannot apply normal means of assessment, however (Mörner, 2001, 2012c). The "methods" used are the following:

1. Claiming what you want to claim without backing it up by observational records. Basically this is what the nuclear industry is doing.

2. Analysing the present seismic records (in Sweden, the nuclear industry selected the time window 1951-1976) and making straight-line extrapolations into the distant future (KBS, 1983; La Pointe et al., 2000).
3. Analysing the palaeoseismic records over the last $13000 \mathrm{yr}$ and multiplying the records for the time period of $100000 \mathrm{yr}$ (Mörner, 2003, 2011, 2012a).

4. Substituting observations for computer modelling of the changes in stress and strain in the bedrock (Lambeck, 2005; Lund et al., 2009).

5. Claiming that we cannot undertake serious and meaningful assessments over such time periods (Mörner, 2001).

\subsection{Claiming what you want}

In the absence of adequate background data for a serious seismic hazard assessment, it may be tempting to give up, and simply claim what you want to claim. Having started nuclear power without first having solved the handling of the highlevel nuclear waste puts an "a posteriori" pressure of "solving" the waste management. One way out of the dilemma was simply to claim that "all works well" and "the waste can be stored under full safety for $100000 \mathrm{yr}$ " (KBS, 1983; SKB, 2011; Posiva, 2012). This is to substitute science for hope.

\subsection{Using seismological records}

Sweden has an excellent seismological record from the beginning of the 19th century (Båth, 1978). Both Sweden and Finland have low to moderately low seismic activity today, whilst it at the time of deglaciation some $10000 \mathrm{yr}$ ago was high to very high (Mörner, 1985, 2003, 2011). A seismologic pattern of events achieved from a time window as short as decades can never provide meaningful seismic hazard assessments for longer-term time periods (as illustrated in Fig. 1). Still, this has been done both in Sweden and Finland.

KBS (1983) analysed a $25 \mathrm{yr}$ period (1951-1976) and made predictions for the next $10^{5}-10^{6} \mathrm{yr}$. This is, of course, to violate the rules of serious hazard assessments. Still, this is what was done. Worse was that it came to form the illusive idea that seismic activity will not pose any problem for a safe deposition in the bedrock for, at least, $100000 \mathrm{yr}$ (SKB, 2011). In Finland, similar views were expressed (e.g. Posiva, 2012), and they even claimed that the safety would last for 1 million years (STUK, 2011).

Assessing their methodology, the present author extrapolated their seismic activity line backwards (Mörner, 1995) and noted that there was a major change in the level of energy release some $50 \mathrm{yr}$ back in time and the occurrence of high-magnitude palaeoseismic events some $10000 \mathrm{yr}$ ago (Fig. 2). Furthermore, in the mid-1980s, a high number of events occurred which violated the extrapolation applied by KBS (1983). This should, of course, have invalidated the methodology applied by the nuclear power industries in Sweden and Finland.

The Swedish nuclear industry (SKB, 2011) still relies on the extrapolation of present-day seismic activity (La Pointe et 


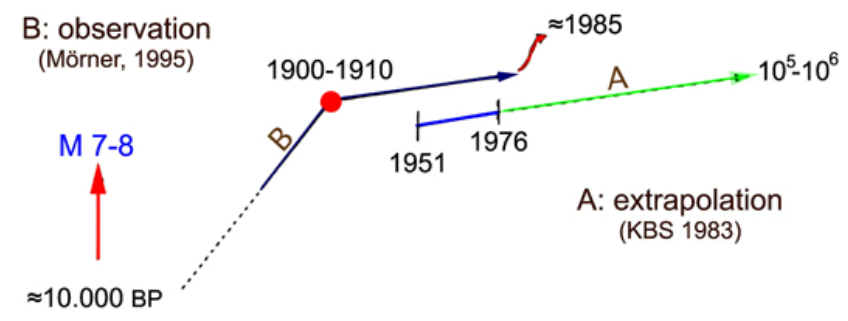

Figure 2. Dimensionless sketch (from Mörner, 1995) illustrating the remarkable long-term prediction by KBS (now: SKB) who analysed the seismicity during $25 \mathrm{yr}, 1951-1975$ (blue line), and made predictions for 100000 to 1 million years (A: green line; KBS, 1983). Mörner (1995; B observation) showed that seismic energy release changed drastically a century ago and that Sweden was a highly seismic area during the time of deglaciation some $10000 \mathrm{yr}$ ago. Furthermore, the seismic activity increased drastically in the mid-1980s (invalidating the green line extrapolation). This indicates that palaeoseismology is the key to serious long-term seismic hazard prediction.

al., 2000), which, they claim, can as a maximum only generate 1 magnitude 6 (M6) event in $100000 \mathrm{yr}$ (or $1 \mathrm{M} 7$ event in 1 million years) in the region of the proposed nuclear waste repository at Forsmark. This is strongly contradicted by our observational facts covering the last $13000 \mathrm{yr}$ (Mörner, 2003, 2011).

\subsection{Using the palaeoseismic records}

With the introduction of palaeoseismological studies in Sweden, it became evident that the seismic activity had changed considerably back in time (e.g. Mörner, 1985, 1991, 2003, 2011; Mörner et al., 2000), primarily as a function of the very high rates of glacial isostatic uplift at the time of deglaciation some $10000 \mathrm{yr}$ ago. The uplift of Fennoscandia has the form of a somewhat skewed cone (Fig. 3) with a maximum uplift of $800 \mathrm{~m}$ in $13000 \mathrm{yr}$. This means very high vertical rates of uplift, which exceed the maximum horizontal plate motions by a factor of ten. At the same time, the horizontal extensional forces in the radial and tangential directions are high, giving strain rates up to two ten potencies higher than today. Therefore, it is not surprising that Fennoscandia, at the time of deglaciation, was a highly seismic area (Fig. 4), despite the fact that it represents an intra-plate shield area.

The "seismic landscape" of Fennoscandia at the time of deglaciation is characterized by frequent high-magnitude palaeoseismic events (Figs. 4-5, Table 2, Appendix A). Mörner (2011) recorded 7 high-magnitude events during $102 \mathrm{yr}$ from varve year 10490 to $10388 \mathrm{BP}$. Several events must have reached a magnitude of 8 to $>8$ (Mörner, 2011). Active faults occur all from northernmost to southernmost Sweden (Mörner, 2004). In northernmost Fennoscandia, there are a number of very large and long fault scarps denoting high-magnitude events (or repeated movements) i.e. in Norway (Olesen, 1988; Dehls et al., 2000), Sweden

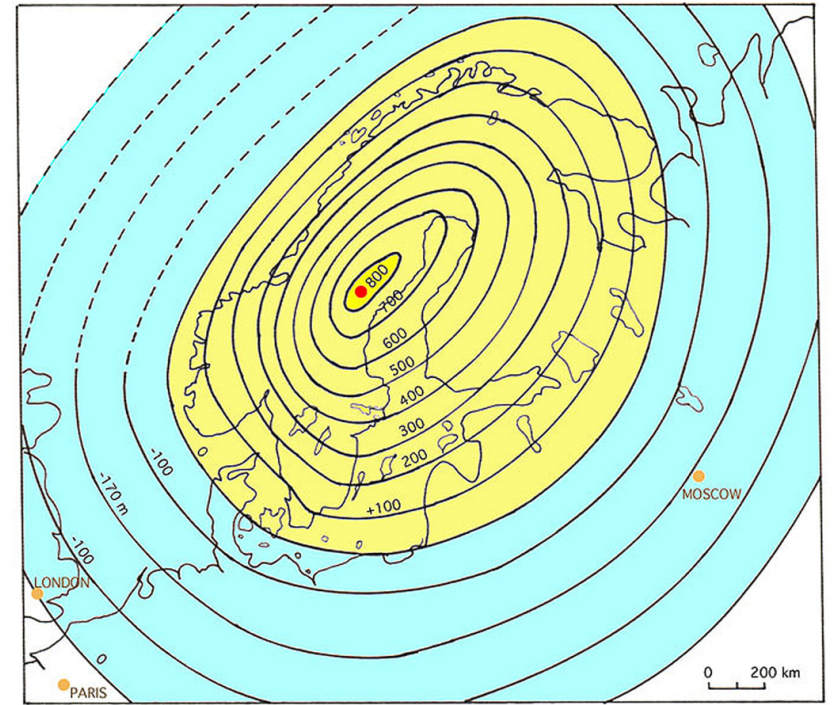

Figure 3. The postglacial uplift cone of Fennoscandia (yellow) with a surrounding subsidence trough (blue). Isobases give uplift and subsidence in metres over the last $15000 \mathrm{yr}$. At the time of deglaciation the rate of uplift peaked with values 10 times higher than that of plate tectonics. The vertical uplift was linked to horizontal extension in the radial and tangential directions.

(Lundqvist and Lagerbäck, 1976; Bäckblom and Stanford, 1989; Lagerbäck, 1990) and Finland (Kujansuu, 1964) as shown on the map of "active tectonics and postglacial palaeoseismics" (Mörner, 2004, Fig. 5).

In palaeoseismology, we study both primary structures (i.e. faults and fractures in direct association to the epicentre) and secondary effects from the ground shaking (i.e. rock and sediment slides, sediment deformations, liquefaction, tsunami events, turbidites, magnetic grain rotation, etc.). By means of different established criteria (Wells and Coppersmith, 1994; Reicherter et al., 2009; Silva et al., 2011), we may assess seismic intensity and magnitude. A key factor is dating. The varve chronology in Sweden offers an exceptional means of dating seismic events to one single varve year, in a few cases even to the season of a year (Mörner, 2003, 2011, 2013a).

With increasing time units, the maximum earthquake magnitude increases dramatically from below 4.8 to well above 8 (Table 1). This implies that we can only achieve a meaningful long-term hazard assessment if the palaeoseismic records (PS) of past earthquakes are included.

\subsubsection{Pattern recorded in Swedish palaeoseismic events}

The main catalogue of palaeoseismic events in Sweden (Mörner, 2003, p. 301-308) used to include 52 separate events. A few additional events have been added (e.g. Mörner, 2008) and today the catalogue includes a total of 62 events (Appendix A). Their temporal distribution is given in 
Table 1. Maximum earthquake magnitudes by time and methodology.

\begin{tabular}{lll}
\hline Methodology & Time unit & $\begin{array}{l}\text { Maximum } \\
\text { magnitude }\end{array}$ \\
\hline Seismology & last $100 \mathrm{yr}$ & $<4.8$ \\
Historical data & last $600 \mathrm{yr}$ & $<5.5$ \\
Late Holocene PS & last $5000 \mathrm{yr}$ & $\gg 6$ to $\sim 7$ \\
Deglacial phase PS & $9-11000 \mathrm{yr} \mathrm{BP}$ & $\gg 8$ \\
\hline
\end{tabular}

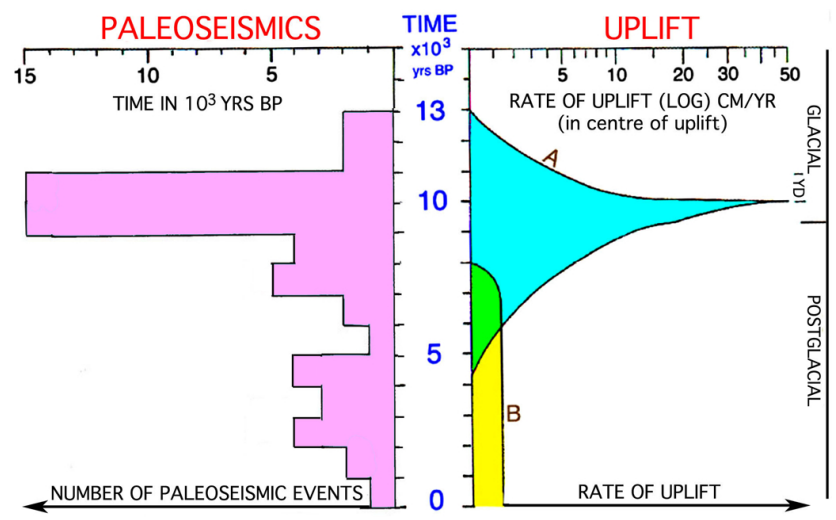

Figure 4. Cumulative distribution over time of the 59 events in the Swedish Paleoseismic-logical Catalogue (Appendix A; Mörner, 2003, 2011). There is a distinct peak in the period $11000-9000 \mathrm{BP}$, which is the time of the peak rate of glacial isostatic uplift (left curve).

Fig. 5. There is a clear maximum at the period of maximum glacial isostatic uplift (Fig. 4).

In five areas, it was possible to establish recurrence diagrams (Fig. 5; cf. Mörner, 2003, p. 310). In four of these areas (the Mälardalen-Stockholm region, the Forsmark region, the Hudiksvall region and the Umea region), there is a clear effect of the isostatic uplift, generating high-frequency events during the early deglacial phase. In the Stockholm region seven events were recorded and dated by varves during a period of $102 \mathrm{yr}$ (Mörner, 2011). This implies very high seismic activity. Also the magnitudes were exceptionally high with events even exceeding M8 (Table 1; Mörner, 2003, 2012). Adams (2005) showed that the distribution of events followed the international relations established by Wells and Coppersmith (1994).

\subsubsection{Mode of recording}

Because of the land uplift, former sea beds and sea bed sediments are now exposed on land where much more detailed investigations can be applied than in a shelf position (Mörner, 2009a). Thanks to this, it was possible to combine multiple criteria in the identification of individual palaeoseismic events (Mörner, 2003, 2011). Furthermore, the glacial clay
Table 2. Time/magnitude distribution of palaeoseismic events in Sweden.

\begin{tabular}{lccccc}
\hline Time unit & M5-6 & M6-7 & M7-8 & M > & Total \\
\hline$\sim 30000$ & 2 & 1 & - & - & 3 \\
$12000-13000$ & - & 1 & - & 1 & 2 \\
$11000-12000$ & - & - & 2 & - & 2 \\
$10000-11000$ & - & 11 & 2 & 2 & 15 \\
$9000-10000$ & 2 & 6 & 4 & 3 & 15 \\
$8000-9000$ & 1 & 2 & 1 & - & 4 \\
$7000-8000$ & 1 & 4 & - & - & 5 \\
$6000-7000$ & - & - & 1 & 1 & 2 \\
$5000-6000$ & - & - & 1 & - & 1 \\
$4000-5000$ & - & 4 & - & - & 4 \\
$3000-4000$ & - & 3 & - & - & 3 \\
$2000-3000$ & 1 & 3 & - & - & 4 \\
$1000-2000$ & 1 & - & - & - & 1 \\
$<1000$ & - & 1 & - & - & 1 \\
\hline Events in total: & 8 & 35 & 12 & 7 & 62 \\
$13000-9000$ & 3 & 20 & 9 & 6 & 38 \\
$8000-0$ & 3 & 15 & 2 & 1 & 21 \\
\hline
\end{tabular}

and silt is annually varved allowing for dating with an annual time resolution (Mörner, 2013a).

In the autumn of varve $10430 \mathrm{vBP}(\sim 10000 \mathrm{cBP})$, a very strong seismic event occurred in the Stockholm and Mälardalen Valley (Mörner, 2003, 2008, 2011). It is recorded by multiple different methods and closely dated at one single varve, and even to the autumn sequence of this varve (Mörner, 2003, 2013a). A combined picture is given in Fig. 6, which allow us to assign an intensity of XII and magnitude of > 8 (Mörner, 2011).

Another palaeoseismic mega-event occurred in varve 9663 vBP (9150 C14 yr BP). It is documented in a similar way by multiple methods (Mörner et al., 2000; Mörner, 2003, 2008, 2011, 2013a; Mörner and Dawson, 2011). The intensity is estimated at XII and the magnitude at $>8$. The characteristics are given in Fig. 7. It represents one of the most well recorded palaeoseismic events in the world.

Even in the Late Holocene, when the main glacial isostatic uplift was virtually over, there are events recorded by multiple methods indicating an intensity of $\mathrm{X}$ and a magnitude of 7 (Mörner, 2009b, 2011). This is important as it increases the seismic hazard from the present-day maximum of M4.8 to M7 (Table 1; cf. Fig. 2).

The total number of palaeoseismic events recorded today is 62. Their temporal distribution is as follows: 3 events at around $30000 \mathrm{BP}, 38$ events during the deglacial period $13000-8000 \mathrm{BP}$ (i.e. $61 \%$ ), and 21 events in the last $8000 \mathrm{yr}$ with 13 in the last $5000 \mathrm{yr}$. Their magnitude distribution is given in Table 2.

In a temporal context, this implies that the maximum magnitudes recorded grow from 4.8 by recent instrumental cover in the following manner back in time: after $109 \mathrm{yr}$ a M5.4 


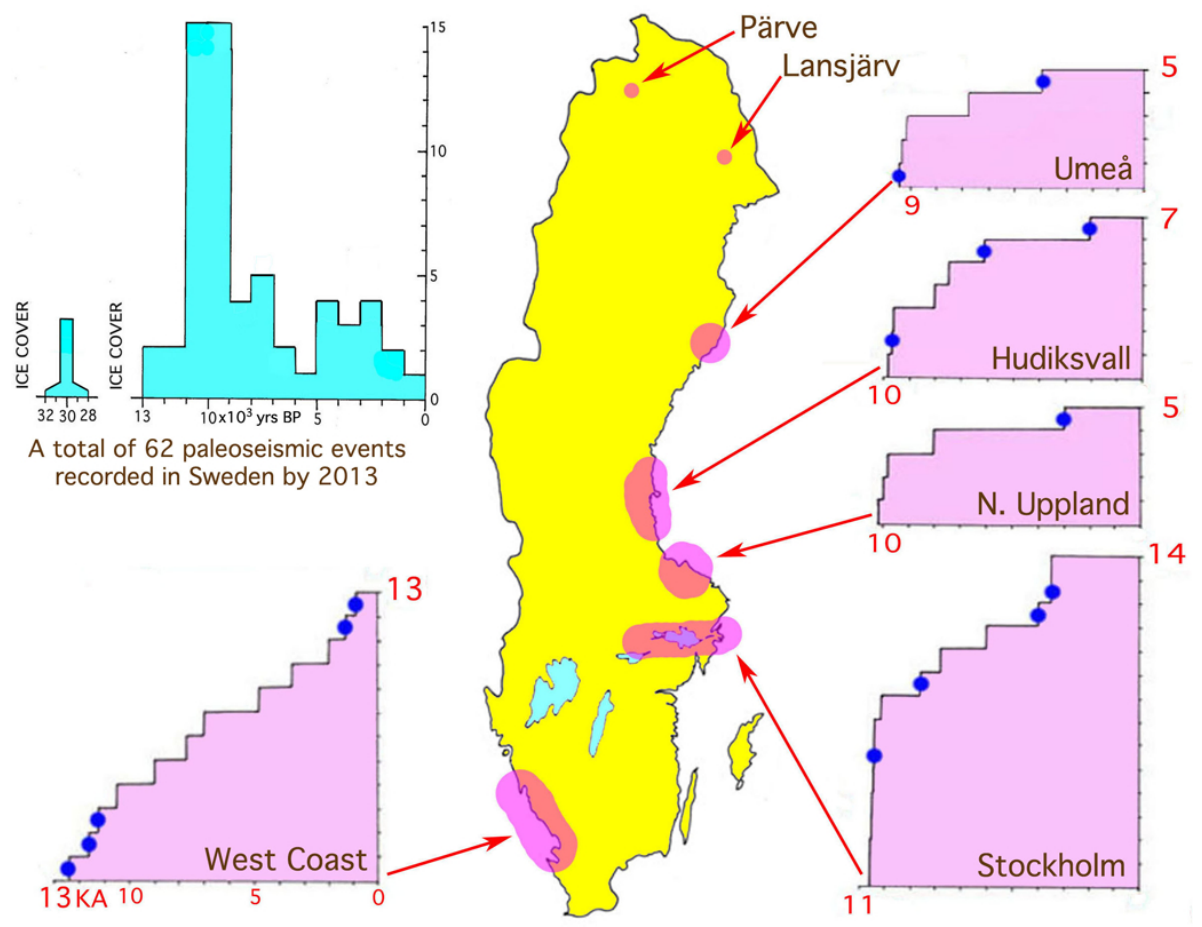

Figure 5. Distribution of palaeoseismic events in Sweden; partly in time (top left; where $50 \%$ of the events fall in the period of maximum rates of uplift; cf. Fig. 4) and partly by area where recurrence diagrams have been constructed for five individual areas (including 44 events, or $71 \%$ of all the events). Blue dots refer to simultaneous tsunami events.

event is observed and recorded, after about $900 \mathrm{yr}$ the first $\mathrm{M} \sim 7$ event is recorded by palaeoseismology, after $6100 \mathrm{yr}$ the first M8 event occurs, and in the period 9000-11000 BP several high-magnitude events are recorded indicating that Sweden by then was a highly seismic region due to the exceptionally high rates of uplift (Mörner, 1991, 2003, 2011).

This is the database (Table 2, Fig. 5, Appendix A) upon which we have to base our estimates on future seismic hazards. The seismological database is far to short and nonrepresentative to be used for long-term predictions (as illustrated in Fig. 2).

\subsubsection{Combination with explosive methane venting tectonics}

Methane occurs in nature in the form of gas or, in sediments and bedrock, in the form of ice (methane hydrate or clathrate). The volumetric relation between the ice and gas phases is $1: 168$, which implies a very large expansion when ice transform into gas. The transition is phase-boundary controlled by temperature and pressure (Mörner, 2011, Fig. 12).

During periods of permafrost, the geothermal gradient is strongly deformed towards colder conditions allowing for methane ice to be formed higher up in the bedrock. During ice ages, the vertical pressure is strongly deformed and methane ice may be formed all the way up to the surface wherever there are voids.
During the postglacial period after an ice age, temperature increases and pressure decreases due to land uplift. Both these processes will affect the stability of an accumulation in the bedrock of methane ice. The ice/gas transition is instantaneous. Consequently, the chances are high that this process will lead to an explosive venting of methane gas (Fig. 8).

This is precisely what we have found in our studies in Sweden (Mörner, 2003, 2011; Mörner and Sjöberg, 2011). The seepage of methane gas through the varved clay left spots of precipitated carbonate (isotopically linked to the deglaciation) and ending in the varve at the sea floor of the $9663 \mathrm{vBP}$ palaeoseismic event (Mörner, 2003, p. 289-294), hence linking this palaeoseismic event (Fig. 7) to a simultaneous transformation of methane ice stored in the bedrock into gas seeping to the sea floor surface. This gas seepage is recorded in numerous cores and sited over a distance of $200 \mathrm{~km}$ from Hudiksvall to Uppsala (Mörner, 2003).

In association with the $9663 \mathrm{vBP}$ event, there are, besides the seismotectonic effects, also records of severe deformation due to explosive methane venting. This is especially clear in the case of the Boda Cave (an old bedrock hill now fractured into a big field of fractured blocks with $2600 \mathrm{~m}$ cave passages in the subsurface). The surface and subsurface are fractured into big blocks, indicating an initial phase of extension followed by a period of contraction (falling back). This deformation is organized around 12 separate centra 


\begin{tabular}{|c|}
\hline THE 10,430 vBP PALEOSEISMIC EVENT \\
\hline $\begin{array}{c}\text { PRIMARY NORMAL FAULT } \\
\text { Reactivation of old East-West fault } \\
\text { Segmentation with } 7 \text { events } 102 \text { years } \\
\text { Total fault length } 400-700 \text { m, vertical throw unknown }\end{array}$ \\
\hline $\begin{array}{l}\text { LATERAL-SYMPATHETIC FAULT } \\
\text { At } 45^{\circ} \text { angle and } 1 \mathrm{~km} \text { north of the main fault, } \\
\text { there is a fault of } 6-8 \mathrm{~m} \text { throw and }>1 \mathrm{~km} \text { length }\end{array}$ \\
\hline $\begin{array}{l}\text { HEAVY BEDROCK FRACTURING } \\
\text { A: numerous sites over an area of } 50 \times 100 \mathrm{~km} \\
\text { B: a "paleoseismograph" indicating epicentre }\end{array}$ \\
\hline $\begin{array}{c}\text { EARTH SLIDES } \\
\text { A: slides recorded at some sites } \\
\text { B: dated at the autumn of varve } 10,430 \text { vBP }\end{array}$ \\
\hline $\begin{array}{l}\text { SHAKING } \\
\text { A: shaking of sand, silt and clay beds recorded } \\
\text { B: shaking of fine particles recorded by magnetic means } \\
\text { C: it is dated at the autumn of varve } 10,430 \mathrm{vBP}\end{array}$ \\
\hline $\begin{array}{c}\text { HEAVY LIQUEFACTION } \\
\text { A: recorded at several sites over an area of } 320 \times 100 \mathrm{~km} \\
\text { B: multiple phases recorded at some sites } \\
\text { C: liquefaction event dated at the autumn of varve } 10,430 \mathrm{vBP}\end{array}$ \\
\hline $\begin{array}{l}\text { STRONG TSUNAMI EVENT } \\
\text { A: recorded at several sites over } 300 \times 400 \mathrm{~km} \\
\text { B: wave height of } 15-20 \mathrm{~m} \text { with opening of the Närke Straight } \\
\text { allowing marine water to enter the Baltic (the Yoldia Sea) } \\
\text { C: the tsunami is dated at the autumn of varve } 10,430 \mathrm{vBP}\end{array}$ \\
\hline $\begin{array}{l}\text { EXTENSIVE TURBIDITE } \\
\text { A: recorded at numerous sites of varved clay } \\
\text { B: extending over an area of } 200 \times 320 \mathrm{~km} \\
\text { C: dated exaxtly at varve } 10,430 \mathrm{vBP}\end{array}$ \\
\hline $\begin{array}{c}\text { MAGNETIC GRAIN ROTATION } \\
\text { A: "seismomagnetization" over } 500 \times 600 \mathrm{~km} \\
\text { B: } 90^{\circ} \text { polarity rotation over } 18 \text { varves }\end{array}$ \\
\hline
\end{tabular}

Figure 6. The 10430 vBP event documented by nine different characteristics (Mörner, 2011).

(Mörner, 2003). We believe that these centra represent centra of methane venting.

The 9663 vBP earthquake was a very strong event with a magnitude $>8$ (Fig. 7; Mörner, 2011). The bedrock is deformed over an area with a radius of $50 \mathrm{~km}$ from the epicentre. Out of numerous sites (maybe on the order of 100), we studied 49 sites in great details. The most extensive deformation occurs at the Boda Cave. This site is located $12.5 \mathrm{~km}$ to the west of the epicentre. At the time of deformation, the site was located about $200 \mathrm{~m}$ below sea level. The mode of deformation seems to be a combination of seismic wave deformation and methane gas venting (Mörner, 2003). This is illustrated in Fig. 9.

Because the ice/gas phase boundary is sensitively controlled by pressure, the seismic wave may trigger a transition from ice to gas (Fig. 9). At the $9663 \mathrm{vBP}$ event, there are 3 sites which we have interpreted as primarily deformed by methane venting tectonics. Because the bedrock deformation covers such great distances away from the epicentre, there

\section{THE 9663vBP PALEOSEISMIC EVENT}

PRIMARY THRUST FAULT

$\sim 20 \mathrm{~m}$ thrust, $\sim 20^{\circ}$ angle, $\sim 50 \mathrm{~m}$ slip fault length $20-150 \mathrm{~km}$

HEAVY BEDROCK FRACTURING

A: some 100 sites (49 investigated in details) over a distance of $50 \mathrm{~km}$ from the epicentre

$\mathrm{B}$ : extensive rock avalanches at some sites

EARTH SLIDES

(obscured by vegetation and sediment-cover)

3-4 slides recorded at the Boda Cave and dated at $9663 \mathrm{vBP}$

HEAVY LIQUEFACTION

A: recorded at 13 sites over an area of $80 \times 40 \mathrm{~km}$

B: 5 separate phases recorded at 2 independent sites

C: liquefaction event dated at varve $9663 \mathrm{vBP}$

STRONG TSUNAMI EVENT

A: recorded at 14 sites over an area of $175 \times 25 \mathrm{~km}$

(probably $300 \mathrm{~km}$ south and east, too)

B: wave-height at least $15 \mathrm{~m}$

C: tsunami event dated at varve 9663 vBP and $9150 \mathrm{C} 14$-years BP

\section{EXTENSIVE TURBIDITE}

$A$ : recorded at 25 varved clay sites in the near field and several additional sites in the far field

$\mathrm{B}$ : extending over an area of $310 \mathrm{~km}$ in $\mathrm{N}-\mathrm{S}$ direction

C: dated exactly at varve 9663 vBP

METHANE VENTING

A: recorded in the varved clay (the "spotted zone")

$\mathrm{B}$ : the spots end sharply with varve $9663 \mathrm{vBP}$

(i.e. the seabed at the time of the event)

C: methane venting tectonic recorded at the Boda Cave and some other sites

Figure 7. The 9663 vBP event documented by seven different characteristics (Mörner, 2011).

may in fact be more localities affected by this mechanism (though this cannot be demonstrated).

There are two cases of violent methane venting tectonics dated at the Late Holocene. It remains unknown whether these events were triggered by the postglacial changes in temperature and isostatic pressure, or were triggered by earthquakes. One occurred 2900 BP just north of Hudiksvall and set up a tsunami wave of $20 \mathrm{~m}$ height (Mörner, 2003, 2011, 2013a; Mörner and Dawson, 2011). The other site is located just south of Stockholm and seems to have occurred about 4000 yr ago (Mörner and Sjöberg, 2011). In both cases huge blocks were thrown up vertically, now resting on the top of a cone of fractured bedrock blocks. 


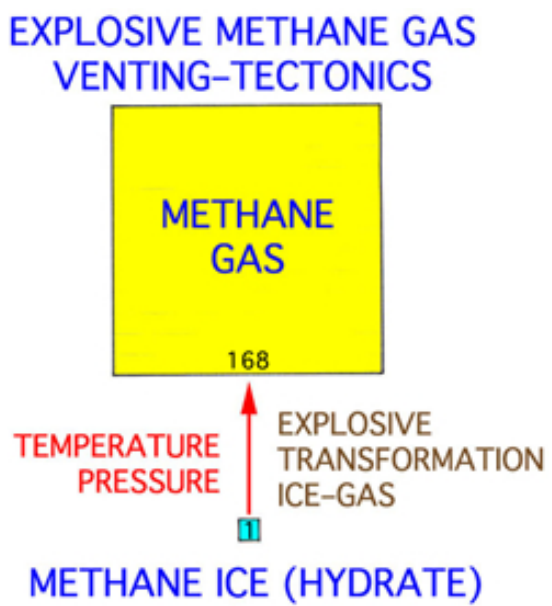

Figure 8. When methane ice in the bedrock transforms into gas, the increase in volume is $1: 168$, which leads to an explosive venting of methane gas. This venting may severely deform the bedrock ("methane venting tectonics") as recorded in Sweden.

\subsection{Computer modelling}

Modelling the stress variations due to the glacial loading history of the Fennoscandian shield (Lambeck, 2005) may be a useful tool for assessing the fracturing with depth (Lund et al., 2009), despite the fact that the model is based on a number of assumptions and uncertainties in the input loading history. As a means of assessing seismic hazard, it is a very blunt tool, however. Therefore, it may not be surprising that it fails in reproducing observed palaeoseismic events (Mörner, 2011, 2012).

Adams (2005) noted that the validity of the loading model (Lambeck, 2005) required that no earthquakes had occurred during the period of ice cover $(\sim 70-15 \mathrm{ka})$. Therefore, it is of great significance that there are records of palaeoseismic activity from around $30000 \mathrm{BP}$ at 4 sites in Sweden (Fig. 10), a major fault in Norway (Feyling-Hanssen, 1966) and several sites in the peri-Baltic region (Bitinas and Lazauskiene, 2011). Furthermore, Löfvendahl and Holm (1981) dated the precipitation of uranium in a large number of fractures to the period of the Last Ice Age, with 6 sites dated at the interval $22-40 \mathrm{kaBP}$.

Consequently, the period of ice cover seems not so seismically calm (Fig. 10) as the model presupposes. This sheds serious doubts on the application of the computer modelling (Lambeck, 2005; Lund et al., 2009; Stephansson et al., 2012).

\subsection{Exceeding our present possibilities}

The time periods involved $(100000 \mathrm{yr}$ in Sweden and 1 million years in Finland) are so immense and incomprehensible that meaningful prediction may certainly be questioned. We may, therefore, talk about predictions "in absurdum" (Mörner, 2001).
The seismic pattern recognized by palaeoseismology (Fig. 1) may successfully provide a seismic hazard assessment for a time period into the future of the same time dimension up, maybe, a couple of doublings (cf. below).

\section{Discussion}

To begin with, we can safely conclude that the present seismological database (Sect. 2.2) is far too short to be used for long-term predictions (Fig. 1) in view of the long-term safety of high-level nuclear waste storage in the bedrock. This becomes evident when the palaeoseismic data are included (Table 1, Figs. 2 and 5, Appendix A). Long-term stress and strain modelling (Sect. 2.4) includes a number of assumptions. All modelling undertaken up to today (e.g. Lambeck and Purcell, 2003; Lambeck, 2005; Lund et al., 2009) fails to reconstruct the palaeoseismic patterns recorded in Sweden and Finland (Mörner, 2003, 2011, 2012). Furthermore, the absence of earthquakes during the period of ice cover required for the applicability of the methodology is violated by observations as illustrated in Fig. 10.

The palaeoseismic database is the only method which can produce patterns of events (i.e. location, magnitude and recurrence frequency) that may allow long-term seismic hazard assessments. The database must be sufficiently complete, however. Such databases covering a very large number of events exist in California (Rockwell, 2010) and Sweden (Mörner, 2003, 2012).

The Swedish Paleoseismic Catalogue is constantly updated. At present it includes 62 events (Appendix A; Mörner, 2003, 2004, 2005, 2011, 2012). As a first, just approximate, way of assessing the seismic hazard of the next $100000 \mathrm{yr}$ (the minimum time requited for nuclear waste storage), we may simply multiply this database by ten (Table 3 ) for all the 59 events recorded after the ice retreat (1), for all events within a radius of $250 \mathrm{~km}$ (2) and for the events recorded in the direct vicinity of the repository proposed at Forsmark in Sweden (3) and at Olkiluoto in Finland (4). The records within the radius of $250 \mathrm{~km}$ (2) seem most relevant, as it fits well with the recommendation by IAEA (2010; cf. above): "The size of the relevant region ... is typically $300 \mathrm{~km}$ ".

This, of course, only gives a hint of the seismic hazard of the next $100000 \mathrm{yr}$ in Sweden and hence the risks associated with the proposed high-level storage of nuclear waste proposed to occur at Forsmark in Sweden and at Olkilouto in Finland. Many additional effects have to be considered, viz. the linkage to glaciations (Figs. 4-5) and the linkage to methane venting tectonics (Fig. 9).

Table 1 shows that there is a very clear increase in the maximum magnitudes back in time. A significant part of this increase is due to the exceptionally high seismicity linked to the deglaciation phase with very strong rates of uplift and rapid extension in the vertical, radial-horizontal and tangential-horizontal dimensions. 

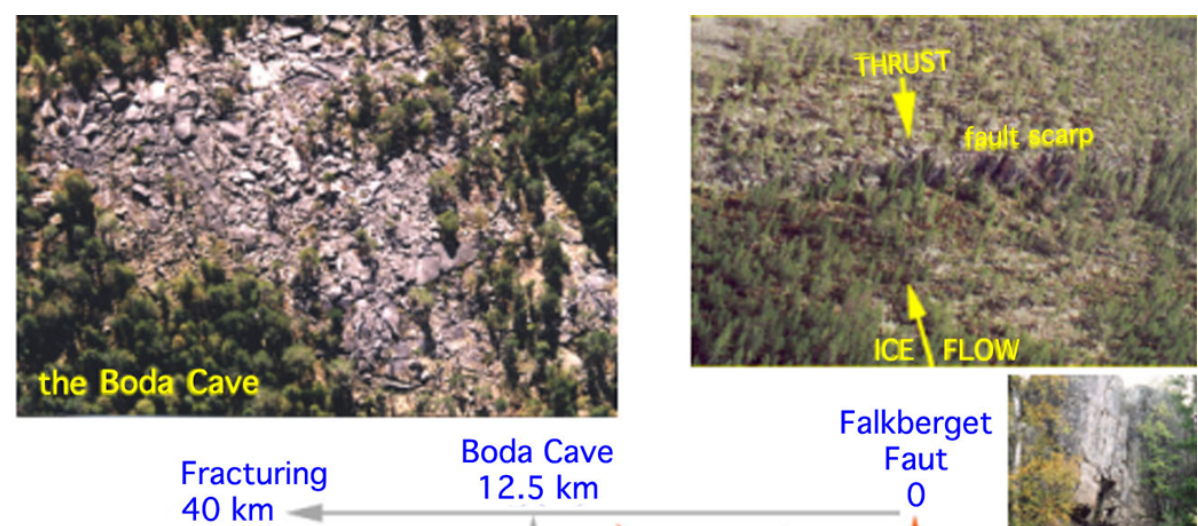

Falkberget

Faut
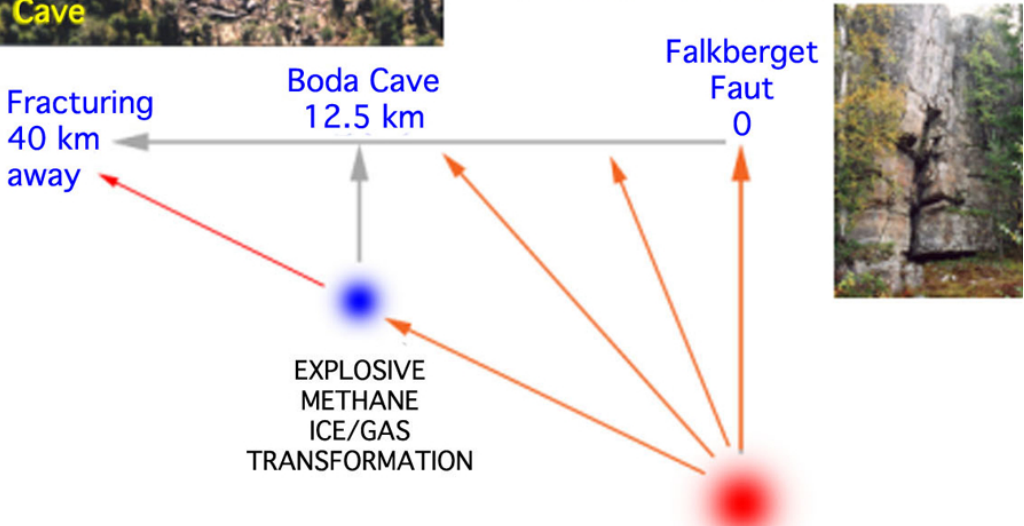

EARTHQUAKE

Figure 9. Proposed interaction of seismic wave propagation at the $9663 \mathrm{vBP}$ event and methane ice/gas transformation generating methane venting tectonics at the Boda Cave in addition to the seismotectonic fracturing recorded, at least, up to $40 \mathrm{~km}$ away from the epicentre (from Mörner, 2003, 2011).

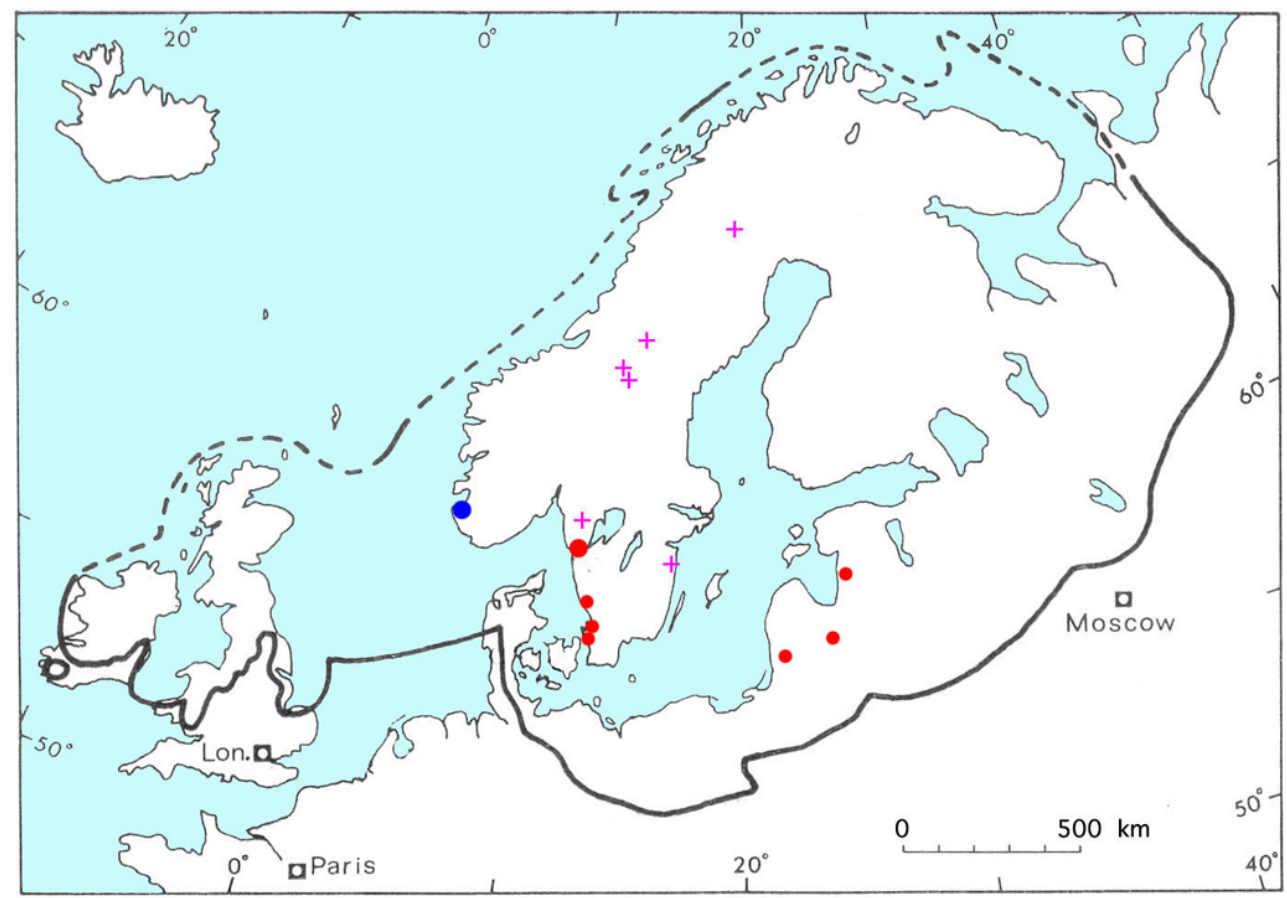

Figure 10. Extension of the ice cap over northern Europe at the glaciation maximum around 20000 yr ago (tick line) and records of palaeoseismic events during the interstadial period around $30000 \mathrm{BP}$; red dots $=$ palaeoseismic liquefaction structures; blue dot $=$ heavy faulting; purple crosses = dated precipitation of uranium in fractures (during this interstadial a substantial ice sheet persisted, but the limits are much debated). 
Table 3. Magnitude distribution of the 62 palaeoseismic events recorded and documented in Sweden up to 2013 (Appendix A), and their 10-fold multiplication to cover the nuclear waste period of $100000 \mathrm{yr}$ for 3 spatial units.

\begin{tabular}{rrr}
\hline \multicolumn{3}{l}{$\begin{array}{l}\text { (1) All the } 59 \text { palaeoseismic events in Sweden } \\
\text { after the Last Ice Age (Appendix A) }\end{array}$} \\
\hline Magnitude & $\begin{array}{r}\text { Number of } \\
\text { events }\end{array}$ & $\begin{array}{r}10 \text {-fold } \\
\text { increase }\end{array}$ \\
\hline$>8$ & 7 & 70 \\
$7-8$ & 12 & 120 \\
$6-7$ & 34 & 340 \\
$<6$ & 6 & 60
\end{tabular}

(2) Aall the 29 palaeoseismic events in the Stockholm-N. Uppland-Hudiksvall area (Fig. 5) plus (+) the 5-6 events on the Finnish side (Fig. 11) within a radius of $250 \mathrm{~km}$ from the proposed repository at Forsmark

\begin{tabular}{|c|c|c|}
\hline$>8$ & 4 & 40 \\
\hline $7-8$ & $3+2$ & 50 \\
\hline $6-7$ & $17+2$ & 190 \\
\hline$<6$ & $5+2$ & 70 \\
\hline \multicolumn{3}{|c|}{$\begin{array}{l}\text { (3) Only the } 5 \text { (or } 6 \text { ) palaeoseismic events } \\
\text { in the direct vicinity of Forsmark }\end{array}$} \\
\hline \multicolumn{3}{|l|}{$>8$} \\
\hline \multicolumn{3}{|l|}{$7-8$} \\
\hline $6-7$ & $4-5$ & $40-50$ \\
\hline$<6$ & 1 & 10 \\
\hline \multicolumn{3}{|c|}{$\begin{array}{l}\text { (4) Only the } 5 \text { palaeoseismic events } \\
\text { in the direct vicinity of Olkiluoto }\end{array}$} \\
\hline \multicolumn{3}{|l|}{$>8$} \\
\hline $7-8$ & 2 & 20 \\
\hline $6-7$ & 2 & 20 \\
\hline$<6$ & 1 & 10 \\
\hline
\end{tabular}

During the last $5000 \mathrm{yr}$ (when the uplift was not significantly higher than today) there were 13 events, several of which reached magnitude 7 . The first magnitude 8 event is recorded at $6100 \mathrm{BP}$. For the last $8000 \mathrm{yr}$, there are 21 events recorded (Table 2). This database can be used for the evaluation of the seismic hazards during the non-glacial intervals of the next $100000 \mathrm{yr}$, with the database of the 13000 to $9000 \mathrm{BP}$ period (Table 2) added for the periods of future deglaciation. At the same time, however, the present database is likely to expand with time, as there are numerous potential events which have not reached the catalogue because further studies and dating remain to be carried out.

Methane venting tectonics (Fig. 9, Sect. 2.3.3) is a novel process, first proposed by Björklund (1990; cf. Sjöberg, 1994) and later documented by us (Mörner, 2003, 2011; Mörner and Sjöberg, 2011). The significance for hazard assessments is that it adds an additional consequence of earth-

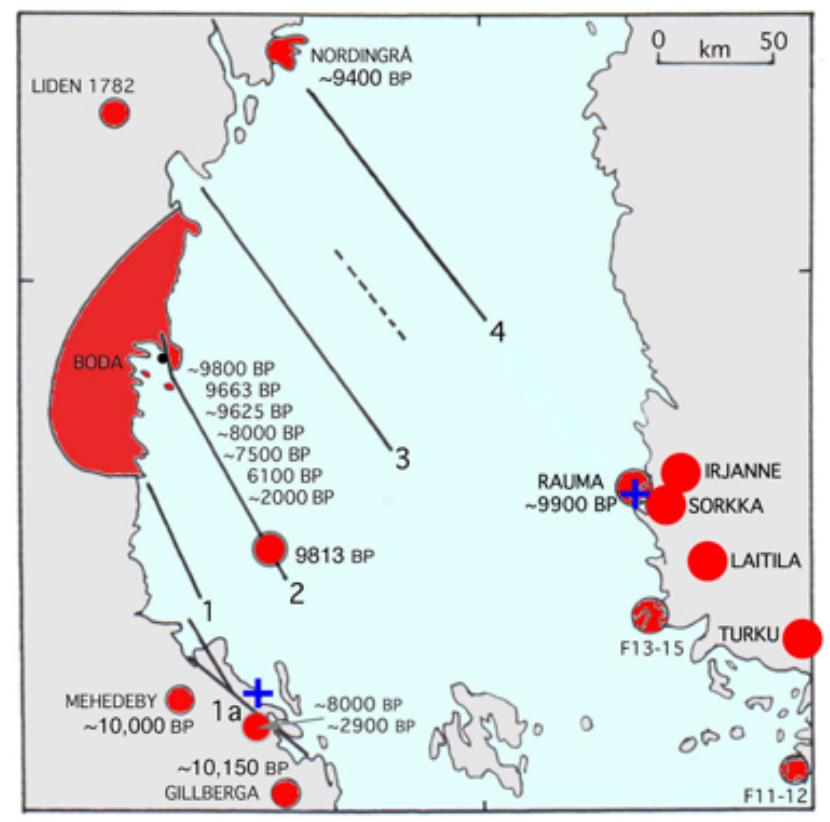

Figure 11. The Bothnian Sea region with all the palaeoseismic events recorded in Sweden (Mörner, 2003, 2009, 2011, 2013a) and Finland (Kuivamäki et al., 1998; Koltainen and Hutri, 2004; Mörner, 2010). Blue crosses mark the location of the proposed repositories of high-level nuclear waste at Forsmark (Sweden) and Olkiluoto (Finland).

quake events, which may significantly increase the bedrock fracturing in horizontal as well as vertical dimensions. Whilst the nuclear power industry claims (Bäckholm and Munier, 2002) that the bedrock fracturing is restricted to a few centimetres of displacement only 50-100 m along regional fracture zones, we observe severe deformation on the order of many decimetres up to metres at distances of 10 to $50 \mathrm{~km}$ from the epicentres (Mörner, 2003, 2011).

Another factor is the spatial distribution of events in relation to the proposed location of nuclear waste storage. As a matter of fact, the region around the Bothnian Sea (where the proposed closed bedrock storages in Sweden and Finland are planned to be located) constitutes a highly seismic region (Fig. 11).

\section{Assessing the seismic hazard for $100000 \mathrm{yr}$}

The above analysis (Sect. 2.2, e.g. Fig. 2) indicates that the available seismic database is useless as a base for long-term assessments. Loading modelling (Sect. 2.4) also does not seem to be a meaningful way forward in assessing the risks not least because some of the basic assumptions have turned out to be wrong (Fig. 10).

The only way forward goes via the analysis of the palaeoseismic database. The Swedish database is extensive (Mörner, 2003, 2005, 2009b, 2011, 2013a). We may consider the entire database (Table 2) or divide it up in dynamic 


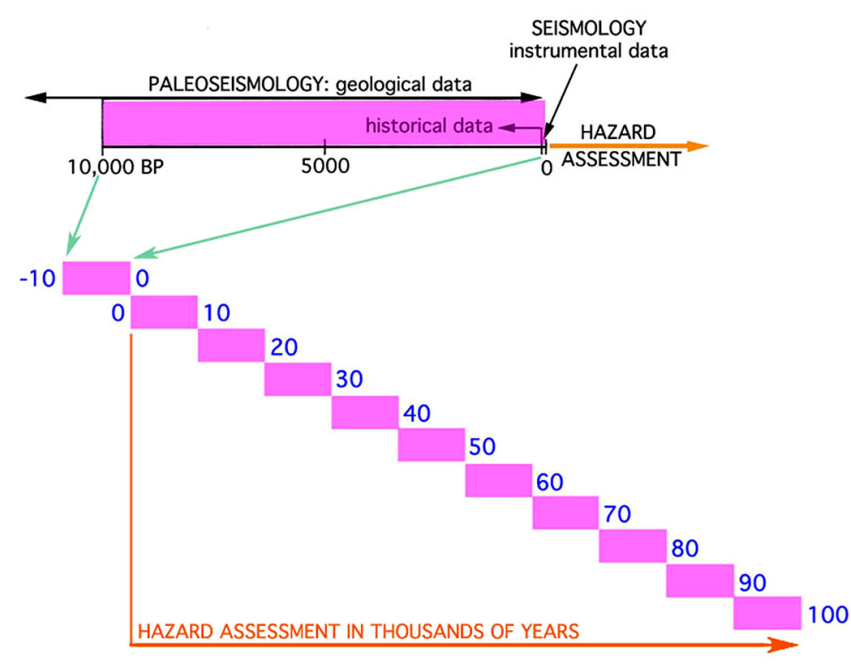

Figure 12. The transformation of a palaeoseismic database into the future $(100000 \mathrm{yr})$ by doubling the original time frame 10 times. However good the base data is, each time doubling implies a deterioration of the quality of hazard assessment. Somewhere, the validity may even break down. Certainly, however, this methodology is superior to the utilization of short seismic records, which must be discarded as meaningless and misleading.

segments: a deglacial phase $13000-8500 \mathrm{BP}$, a transitional phase $8500-5500 \mathrm{BP}$ and a postglacial phase $5000-0 \mathrm{BP}$. The analyses may also be confined to the near field of the repositories (Fig. 11). These are practical matters that will provide somewhat different results. Whatever methodology we apply, the seismic hazard assessment will provide magnitudes and frequencies that by far exceed the values given by the nuclear power authorities (SKB, 2011; Posiva, 2012).

In theory, we begin with the database available and, by different means and methods, extend it into the future. To extend the database into the future over a time period as long as the database itself seems correct and straightforward. Each time doubling thereafter will decrease the validity - by how much, we may argue. But it is likely to deteriorate with time from "reliable" to "uncertain", and perhaps even to "meaningless" and, still worse, to "misleading" (if so the predictions are certainly carried "in absurdum"; Mörner, 2001). This is illustrated in Fig. 12.

To make hazard assessments over such an immense time period as $100000 \mathrm{yr}$ is basically absurd. In the best cases, we may be limited to hints about what actually may be the case. For safety reasons, it might be wiser simply to multiply the existing database into the future as illustrated in Fig. 12. In this case, we would obtain a likely seismicity of such a high frequency and such high magnitudes (Table 3) that no safety - rather the opposite - would seem to apply for the high-level nuclear waste repositories proposed at Forsmark in Sweden and at Olkiluoto in Finland (both proposing a closed storage 400-500 $\mathrm{m}$ down in the bedrock).

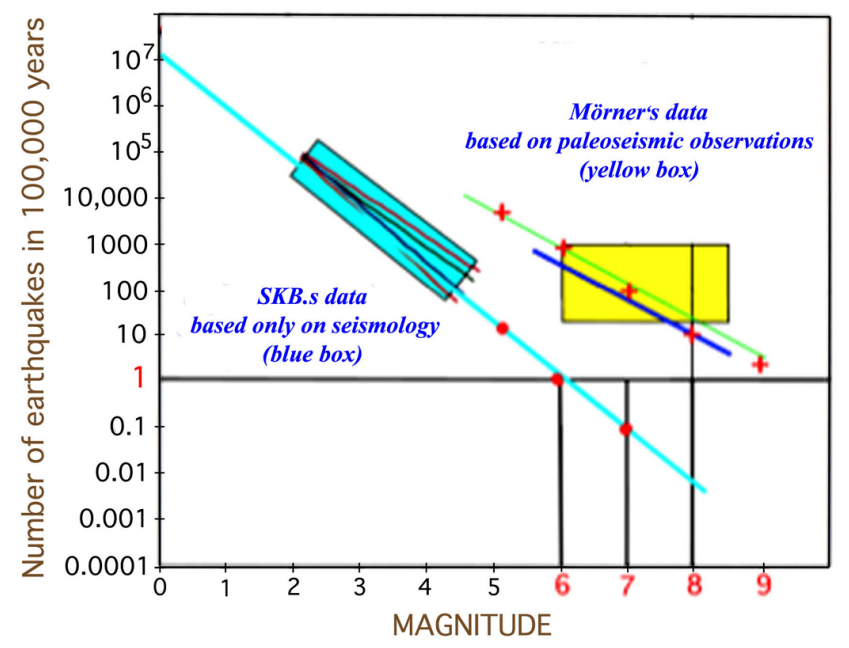

Figure 13. Seismic hazard assessment for the next $100000 \mathrm{yr}$, partly (in blue) as done by La Pointe et al. (2000) on the basis of present seismological data (blue box and extrapolated line suggesting 10 M5 events, 1 M6 event and 0.1 M7 events in $100000 \mathrm{yr}$ for the Forsmark area), and partly by converting the palaeoseismic observational records (yellow box: Mörner, 2003, 2011) in a similar way to the 100000 situation (suggesting 10000 M5 events, 1000 M6 events, 100 M7 events, 10 M8 events and a few M9 events for the region with a radius of $250 \mathrm{~km}$ around Forsmark).

As geologists, we might prefer to stay out of such hazardous predictions. This, however, would be to leave the field open for any kind of speculative evaluations (Sects. 2.2, 2.4 and 2.5). We therefore seem forced to do what we can, and that is not better than the mode of forecasting illustrated in Fig. 12.

In Fig. 13, I have applied the same method used by La Pointe et al. (2000) to transfer present-day seismic data over a $100000 \mathrm{yr}$ period to our Swedish palaeoseismic database (Appendix A). The SKB assessment, based solely on a far too short seismological time series, can surely be discarded as directly misleading (cf. Fig. 2). The assessment based on palaeoseismic observations is much better (cf. Fig. 12). Still, the uncertainties are so large that it seems rather to provide only a hint of possible seismicity over the future $100000 \mathrm{yr}$.

Assessing the problem of uncertainties involved in Fig. 13, one may simply extend the width of the blue and yellow boxes to the line of 1 event in $100000 \mathrm{yr}$ (Mörner, 2012b). Doing so, the seismological data would provide a range from 5.5 to 7.2 (in significant contrast to the $1 \mathrm{M} 6$ scenario of SKB), and the yellow box a range from 7.3 to 10.0 (where 9.5 may be held as a theoretical maximum). The green line in Fig. 13 gives some sort of mean value of the palaeoseismic database, and this is probably the best, though still quite approximate, seismic hazard assessment we can do today for the region with a radius of $250 \mathrm{~km}$ around the Forsmark site (also applicable for the Olkiluoto site). 


\section{Conclusions}

Storage of high-level nuclear waste in the bedrock has forced us to attempt to make seismic hazard assessments for a time period of, at least, $100000 \mathrm{yr}$. This almost impossible task is something that must be handled on the basis of an extensive palaeoseismic database.

The following conclusions are drawn:

- The nuclear industries (SKB in Sweden and Posiva in Finland) make far too optimistic statements on the longterm seismicity, primarily based on current seismic data and in general ignoring available palaeoseismic data.

- The seismic database is far too short to be applicable in longer-term hazard assessments. Furthermore the events are not representative of long-term frequency and magnitude (Table 1, Fig. 2).

- Loading modelling seems far too crude for serious hazard assessments. Furthermore, it is seriously contradicted in basic assumptions (Fig. 10) and in the fact that it fails to produce the observed events in deglacial and postglacial times (Table 2).
- The only meaningful hazard assessments must be based on available palaeoseismic data. We may do this in different ways, viz. by transferring the entire database into the future (Table 3, Fig. 13), by dividing it up in deglacial and postglacial time segments (cf. Table 2), or by confining the analysis to the site-specific cases (Fig. 11). The results will differ, but the main answer is clear (Fig. 13): there will be far too many and far too strong events in the future to allow for a statement that a closed repository in the bedrock of KBS-3 type (the concept proposed for the repositories in Sweden and Finland) will stay intact over the required time period of at least $100000 \mathrm{yr}$. The opposite seems rather to be the case: no safe deposition.

The only outcome of this "dead-end situation" seems to be a switch to a different methodology. We have previously proposed a dry rock deposition where the waste remains accessible, controllable, re-usable, destructible and movable (Mörner, 2001, 2013b; Cronhjort and Mörner, 2004).

Edited by: S.-A. Ouadfeul

Reviewed by: two anonymous referees 


\section{Appendix A}

\section{Paleoseismic Catalogue of Sweden II}

Table A1. The Paleoseismic Catalogue of Sweden includs 62 palaeoseismic events as of May 2013 (the 1st catalogue of 2003 included 52 events; Mörner, 2003; cf. 2011). Age of event: vBP = varve years before present; cBP = C14 yr before present (1950). Region: as given in Mörner (2003, p. 302). Reference (Ref.): gives main paper of event description as listed below. Area affected: spatial distribution of palaeoseismic records of event in question. Criteria: $\mathrm{PF}=$ primary fault; $\mathrm{RD}=$ bedrock deformation; $\mathrm{SD}=$ sediment deformation; $\mathrm{VD}=$ varve deformation; $\mathrm{SL}=$ slide or avalange; $\mathrm{LF}=$ liquefaction; $\mathrm{TS}=$ tsunami $\mathrm{T}=$ turbidite $\mathrm{MV}=$ methane venting; $\mathrm{MVT}=$ methane venting tectonics $(2,3,8)$; $\mathrm{QM}=$ Quaternary morphology; $\mathrm{PM}=$ palaeomagnetism (11). Magnitude (Magn.): relative magnitude values deduced from structural criteria.

\begin{tabular}{|c|c|c|c|c|c|}
\hline Age of event & Region & Ref. & Area affected & Criteria & Magn. \\
\hline$\sim 30000 \mathrm{cBP}$ & Gothenburg & 1 & regional & LF, SL & $>6$ \\
\hline$\sim 30000 \mathrm{cBP}$ & Glumslöv & 1 & local-regional & $\mathrm{LF}$ & $>5-6$ \\
\hline$\sim 30000 \mathrm{cBP}$ & Förslövsholm & 1 & local-regional & LF & $>5-6$ \\
\hline $12400 \mathrm{cBP}$ & South Sweden & 2 & $300 \times 400 \mathrm{~km}$ & $\mathrm{SL}, \mathrm{T}, \mathrm{T}, \mathrm{PM}$ & $\gg 8$ \\
\hline$\sim 12000 \mathrm{cBP}$ & Oskarshamn & 2 & local-regional & $\mathrm{PF}, \mathrm{RD}, \mathrm{QM}$ & $6-7$ \\
\hline $11600 \mathrm{cBP}$ & Halland & 2 & $>125 \times 50 \mathrm{~km}$ & LF, SD, TS, SL, QM & $>7$ \\
\hline $11250 \mathrm{cBP}$ & Halland & 2 & $>100 \times 50 \mathrm{~km}$ & $\mathrm{SD}, \mathrm{SL}, \mathrm{LF}, \mathrm{TS}$ & $\sim 7$ \\
\hline$<10700 \mathrm{cBP}$ & Halland & 2 & local & $\mathrm{SD}, \mathrm{SL}, \mathrm{LF}$ & $>6$ \\
\hline$<10560 \mathrm{vBP}$ & Södermanland & 2 & local-regional & $\mathrm{PF}$ & $>6$ \\
\hline$<10550 \mathrm{vBP}$ & Södermanland & 2 & regional & LF & $>7$ \\
\hline$<10550 \mathrm{vBP}$ & Södernamland & 2 & regional & $\mathrm{LF}$ & $6-7$ \\
\hline $10490 \mathrm{vBP}$ & Stockholm & 2 & local-regional & VD & $6-7$ \\
\hline $10469 \mathrm{vBP}$ & Mälardalen & 2 & $>80 \times 20 \mathrm{~km}$ & $\mathrm{RD}, \mathrm{SD}, \mathrm{VD}, \mathrm{LF}, \mathrm{QM}$ & $6-7->7$ \\
\hline $10447 \mathrm{vBP}$ & Stockholm & 2 & local-regional & $\mathrm{RD}, \mathrm{VD}, \mathrm{QM}$ & $6-7$ \\
\hline aut $10430 \mathrm{vBP}$ & Mälardalen & 2,3 & $>320 \times 100 \mathrm{~km}$ & $\begin{array}{l}\text { PF, RD, SL, LF, VD, } \\
\text { TS, T, QM, PM }\end{array}$ & $\gg 8$ \\
\hline $10410 \mathrm{vBP}$ & Mälardalen & 2,3 & local-regional & $\mathrm{RD}, \mathrm{SD}, \mathrm{VD}, \mathrm{T}$, & $6-7$ \\
\hline$\sim 10400 \mathrm{vBP}$ & Mälardalen & 2,3 & regional & $\mathrm{SD}, \mathrm{LF}, \mathrm{VD}$ & $6-7$ \\
\hline $10388 \mathrm{vBP}$ & Mälardalen & 3,4 & regional & $\mathrm{SD}, \mathrm{VD}, \mathrm{LF}, \mathrm{TS}$ & $\sim 8->8$ \\
\hline$\sim 9850 \mathrm{cBP}$ & Bohuslän & 2 & local-regional & PM & $>6$ \\
\hline$\sim 10150 \mathrm{vBP}$ & Uppland-1 & 2 & regional & $\mathrm{RD}, \mathrm{T}$ & $\sim 7$ \\
\hline $9600 \mathrm{cBP}$ & Billingen & 2 & local-regional & SL, LF, PM & $>6$ \\
\hline $10000 \mathrm{vBP}$ & Uppland-2 & 2,4 & regional & $\mathrm{RD}, \mathrm{SD}, \mathrm{VD}, \mathrm{LF}, \mathrm{PM}$ & $\sim 7$ \\
\hline $10000 \mathrm{vBP}$ & Uppland-2b & 12 & local & $\mathrm{RD}, \mathrm{SD}$ & $\sim 6$ \\
\hline $9800 \mathrm{vBP}$ & Hudiksvall-1 & 2 & local-regional & $\mathrm{RD}, \mathrm{VD}$ & $>6$ \\
\hline $9813 \mathrm{vBP}$ & Bothnian Sea & 2 & regional & VD, QM, MV & $6-7$ \\
\hline 9663 vBP & Hudiksvall-2 & 2 & $100 \times 50 \mathrm{~km}$ & PF, RD, SL, LF, TS, VD & \\
\hline & & & & T, MV, MVT, QM & $\sim 8->8$ \\
\hline 9652 vBP & Hudiksvall-3 & 2 & local & SD, LF, VD & $5-6$ \\
\hline $9620 \mathrm{vBP}$ & Hudiksvall-4 & 2 & local-regional & $\mathrm{RD}$ & $6-7$ \\
\hline 9428 vBP & Umåe area-1 & 2,4 & regional & $\begin{array}{l}\text { RD, SD, SL, LF, VD, } \\
\text { T, TS?, PM }\end{array}$ & $>7$ \\
\hline$\sim 9400 \mathrm{vBP}$ & Höga Kusten & 2 & local-regional & $\mathrm{RD}$ & $6-7$ \\
\hline 9293 vBP & Umeå area-2 & 2,4 & regional & PF, SD, SL, LF, VD & $>7$ \\
\hline 9239 vBP & Jämtland & 2 & regional & VD, T, LF? & $>6 ?$ \\
\hline$\sim 9200 \mathrm{vBP}$ & Skellefteå area & 5 & regional & $\mathrm{PF}, \mathrm{SL}$ & $7->7$ \\
\hline $9170 \mathrm{vBP}$ & Umeå area-3 & 4 & regional & PF & $>7$ \\
\hline$\sim 9150 \mathrm{vBP}$ & Lansjärv, Norrb. & 6 & regional & $\mathrm{PF}$ & $>8$ \\
\hline$\sim 9100 \mathrm{vBP}$ & Lainio, Norrbot. & 5 & local-regional & $\mathrm{PF}$ & $\sim 7$ \\
\hline$\sim 9100 \mathrm{vBP}$ & Lansjärv, Norrb. & 5 & regional & $\mathrm{PF}$ & $>8$ \\
\hline$\sim 9000 \mathrm{cBP}$ & Halland & 2 & local & SL & $>5$ \\
\hline$\sim 8500 \mathrm{vBP}$ & Storuman area & 5 & local & $\mathrm{RD}$, SD? & $6-7$ \\
\hline $8600 \mathrm{cBP}$ & Sörmland & 2 & regional & SL, LF, TS & $6-7$ \\
\hline$\sim 8000 \mathrm{cBP}$ & Hudiksvall-5 & 2 & regional & $\mathrm{PF}, \mathrm{RD}, \mathrm{SL}, \mathrm{LF}$ & $>7$ \\
\hline$\sim 8000 \mathrm{cBP}$ & Uppland-4 & 4,1 & regional & TS & $5-6$ \\
\hline$\sim 7800 \mathrm{cBP}$ & Åker-Turinge & 2 & local-regional & $\mathrm{SL}, \mathrm{LF}, \mathrm{T}, \mathrm{QM}$, & $6-7$ \\
\hline$\sim 7700 \mathrm{cBP}$ & Bjäre Peninsula & 2 & local-regional & $\mathrm{LF}$ & $6-7$ \\
\hline$\sim 7500 \mathrm{cBP}$ & Hudiksvall-6 & 2 & regional & $\mathrm{PF}, \mathrm{RD}$ & $>6$ \\
\hline$\sim 7500 \mathrm{cBP}$ & Halland & 2 & local & SL, LF & $>5-6$ \\
\hline$\sim 7000 \mathrm{cBP}$ & Bjäre Peninsula & 2 & local-regional & LF & $>6$ \\
\hline
\end{tabular}


Table A1.Continued.

\begin{tabular}{|c|c|c|c|c|c|}
\hline Age of event & Region & Ref. & Area affected & Criteria & Magn. \\
\hline $6680 \mathrm{vBP}$ & Umeå area-4 & 4 & $>100 \mathrm{~km}$ & $\mathrm{RD}, \mathrm{SL}$ & $\gg 7$ \\
\hline$\sim 6100 \mathrm{cBP}$ & Hudiksvall-7 & 2 & $>100 \times 10 \mathrm{~km}$ & LF, TS & $>8$ \\
\hline$\sim 5700 \mathrm{cBP}$ & Billingen area & 2 & regional & SD, SL, LF & $\sim 7$ \\
\hline$\sim 4800 \mathrm{cBP}$ & Bjäre Peninsula & 2,7 & local-regional & $\mathrm{PF}, \mathrm{RD}, \mathrm{SL}, \mathrm{LF}$ & $\sim 7$ \\
\hline $4300 \mathrm{cBP}$ & Umeå area-5 & 2,4 & local-regional & $\mathrm{SD}, \mathrm{LF}, \mathrm{TS}$ & $6-7$ \\
\hline$\sim 4000 \mathrm{cBP}$ & Sörmland & 2 & local & SL, TS & $\sim 6$ \\
\hline$? \sim 4000 \mathrm{cBP}$ & Södertörn & 8 & local & MVT & $6-7$ \\
\hline$\sim 3500 \mathrm{cBP}$ & Bjäre Peninsula & 2,7 & local-regional & PF, SL & $\sim 7$ \\
\hline$\sim 3300 \mathrm{cBP}$ & Sörmland & 7 & local & SL & $\sim 6$ \\
\hline$\sim 3250 \mathrm{cBP}$ & Mälardalen & 2,7 & local & PF, RD, SL, LF, TS, QM & $\sim 7$ \\
\hline$\sim 2900 \mathrm{cBP}$ & Forsmakr & 7 & regional & $\mathrm{TS}, \mathrm{T}$ & $6-7$ \\
\hline$\sim 2900 \mathrm{cBP}$ & Brantevik & 9 & local-regional & $\mathrm{RD}$ & $\sim 6->6$ \\
\hline$\sim 2000 \mathrm{cBP}$ & Hudiksvall & 7,10 & local-regional & MVT, TS & 7 \\
\hline$\sim 2000 \mathrm{cBP}$ & Bjäre Peninsula & 2,7 & local & SL, LF & $\sim 6$ \\
\hline$\sim 1300 \mathrm{cBP}$ & Bjäre Peninsula & 2 & local & SL & $>5$ \\
\hline$\sim 900 \mathrm{cBP}$ & Bjäre Peninsula & 2,7 & local-regional & PF, SL, TS & $\sim 7$ \\
\hline \multicolumn{6}{|c|}{ and a few "historical events" outside the main catalogue added for comparison: } \\
\hline $1497 \mathrm{AD}$ & Vänern area & & & local & 4.8 \\
\hline$\sim 1750 \mathrm{AD}$ & Bohuslän & & local & & $\sim 5 ?$ \\
\hline $1759 \mathrm{AD}$ & off Bohuslän & & local & & 5.3 \\
\hline $1782 \mathrm{AD}$ & Liden area & 2 & local & SL, LF, TS & $>5.5$ \\
\hline 1904 AD & Bohuslän-Oslo & & regional & & 5.4 \\
\hline
\end{tabular}

Ref.: ${ }^{1}$ Mörner (Fig. 10; 2013c); ${ }^{2}$ Mörner (2003); ${ }^{3}$ Mörner (2011); ${ }^{4}$ Mörner (2008); ${ }^{5}$ Lagerbäck (1990); ${ }^{6}$ Lundqvist and Lagerbäck (1976); ${ }^{7}$ Mörner (2009); ${ }^{8}$ Mörner and Sjöberg (2011); ${ }^{9}$ Mörner (2012); ${ }^{10}$ Mörner and Dawson (2011); ${ }^{11}$ Mörner and Sun (2008); ${ }^{12}$ Lagerbäck et al. (2005).

\section{References}

Adams, J.: On the probable rate of magnitude $\geq 6$ earthquakes close to a Swedish site during the glacial cycle, in: Expert panel elicitation of seismicity following glaciation in Sweden, edited by: Hora, S. and Jensen, M., Statens Strålskyddsinstirut, SSI report 2005: 20, 2005.

Bäckholm, G. and Munier, R.: Effects of Earthquakes on the Deep Repository for Spent Fuel in Sweden on Case Studies and Preliminary Model Results, Swedish Nuclear Fuel and Waste Management Co., SKB, TR-02-24, 2002.

Bäckblom, G. and Stanford, R. (Eds.): Interdisciplinary study of post-glacial faulting in the Lansjärv area northern Sweden 19861988, SKB TR-89-31, Stockholm, 184 pp., 1989.

Båth, M.: Energy and tectonics of Fennoscandian earthquakes, Tectonophysics, 50, 9-17, 1978.

Bitinas, A. and Lazauskiene, J.: Implications of the paleoseismicity of the eastern Baltic Sea region, Abstracts, 18th INQUA Congress, Bern, Switzerland, 2011.

Björklund, A.: Methane venting as a possible mechanism for glacial plucking and fragmentation of Precambrian crystalline bedrock, Geol. Fören. Stockholm Förhandl., 112, 329-333, 1990.

Cronhjort, B. and Mörner, N.-A.: A question of dry vs wet. The case for Dry Rock Disposal of nuclear waste, Radwaste Solutions, May/June, 44-47, 2004.

Dehls, J. F., Olesen, O., Olsen, L., and Blikra, L. H.: Neotectonic faulting in northern Norway; the Stuoragurra and Nordmannvik- dalen postglacial fauls, Quaternary Sci. Rev., 19, 1447-1460, 2000.

Feyling-Hanssen, R. W.: Geologiske observasjoner i Sandnesområdet, Norges Geol. Undersökelse, 242, 26-43, 1966.

IAEA: Seismic hazards in site evaluation for nuclear installations. Specific safety guide, IAEA Safety Standards Series, No. SSG-9, $1-60,2010$.

KBS (Svensk Kärnbränsle Säkerhet): Kärnbränslecykelns slutsteg, Använt kärnbränske-KBS-3. Vol. II: Geologi, 1-90, 1983.

Kotilainen, A. and Hutri, K.-L.: Submarine Holocene sedimentary disturbances in the Olkiluoto area of the Gulf of Bothnia: a case of postglacial paleoseismicity, Quaternary Sci. Rev., 23, 1125$1135,2004$.

Kuivamäki, A., Vuorela, P., and Paananen, M.: Indications of Postglacial and Recent Bedrock Movements in Finland and Russian Karelia, Geol. Survey Finland, Rep. YST-99, 1-92, 1998.

Kujansuu, R.: Recent faults in Finnish Lapland, Geologi, 16, 1-30, 1964 (in Finnish).

Lagerbäck, R.: Late Quaternary faulting and paleoseismicity in northern Sweden, with particular reference to the Lansjärv area, northern Sweden, Geol. Fören. Stockh. Förh., 112, 333-354, 1990.

Lagerbäck, R., Sundh, M., Svedlund, J. O., and Johansson, H.: Forsmark site investigation. Searching for evidence of late- or postglacial faulting in the Forsmark region, SKB, R-05-51, 1-50, 2005.

Lambeck, K.: Glacial load stresses. Can existing faults or other zones of crustal weakness be reactivated during glacial cycles?, 
in: Expert panel elicitation of seismicity following glaciation in Sweden, edited by: Hora, S. and Jensen, M., Statens Strålskyddsinstirut, SSI report 2005, 20, 85-106, 2005.

Lambeck, K. and Purcell, A.: Glacial rebound and glacial stress in Finland, Posiva Oy, Posiva report 2003-10, 2003.

La Pointe, P., Cladouhos, T., Outters, N., and Follin, S.: Evaluation of the conservativness of the methodology for estimating earthquake-induced movements of fractures intersecting canisters, SKB, TR-00-08, 2000.

Löfvendahl, R. and Holm, E.: Radioactive diseqilibria and apparent ages of secondary uranium minerals from Sweden, Lithos, 14, 1-44, 1981

Lund, B., Schmidt, P., and Hieronymus, C.: Stress evolution and fault stability during the Weichselian glacial cycle, SKB, TR-+9151-106, 2009.

Lundqvist, J. and Lagerbäck, R.: The Pärve fault: a late-glacial fault in the Precambrian of Swedish Lapland, Geol. Fören Stockholm Förh., 98, 54-61, 1976.

McCalpin, J. P. (Ed.): Paleoseismology, International Geophysics, Academic Press, 95, 1-647, 2009.

Mörner, N.-A.: Paleoseismicity and geodynamics in Sweden, Tectonophysics, 117, 139-153, 1985.

Mörner, N.-A.: Global Change: the lithosphere: internal processes and Earth's dynamicity in view of Quaternary observational data, Quatern. Int., 2, 55-62, 1989.

Mörner, N.-A.: Intense earthquakes and seismotectonics as a function of glacial isostasy, Tectonophysics, 188, 407-410, 1991.

Mörner, N.-A: Paleoseismicity - The Swedish case, Quatern. Int., 25, 75-79, 1995.

Mörner, N.-A.: In absurdum: long-term predictions and nuclear waste handling, Eng. Geol., 61, 75-82, 2001.

Mörner, N.-A.: Paleoseismicity of Sweden - a novel paradigm. A contribution to INQUA from its Sub-commission on Paleoseismology at the 16th International INQUA Congress in Reno, Nevada, P\&G print, 2003, 1-320, 2003.

Mörner, N.-A.: Active faults and Paleoseismicity in Fennoscandia, especially Sweden. Primary structures and secondary effects, Tectonophysics, 380, 139-157, 2004.

Mörner, N.-A.: An investigation and catalogue of paleoseismology in Sweden, Tectonophysics, 408, 265-307, 2005.

Mörner, N.-A.: Paleoseismicity and Uplift of Sweden, Guidebook, Excursion 11 at 33rd IGC, Oslo 2008, 1-107, www.33IGC.org, 2008.

Mörner, N.-A.: Paleoseismics in an uplifted, former shelf, area. IGCP-526: Risks, Resources, and Records of the Past on the Continental Shelf, 3rd Annual Meeting, Rabat, Morocco, Abstracts, 2009a.

Mörner, N.-A.: Late Holocene earthquake geology in Sweden, Geol. Soc. Spec. Publ., 316, 179-188, 2009b.

Mörner, N.-A.: Seismotektoniska grottor i Finland, Grottan, 45, 6$14,2010$.

Mörner, N.-A.: Paleoseismology: The application of multiple parametres in four case studies in Sweden, Quatern. Int., 242, 65-75, 2011.

Mörner, N.-A: Seismic hazard assessment on a nuclear waste time scale. 3rd INQUA-IGCO-567 International Workshop on Active Tectonics, Paleoseismology and Archaeoseismology, Morelia, Mexico, 19-24 November 2012, INQUA-IGCP 567 Proceedings, 3, 31-134, 2012a.
Mörner, N.-A.: Utvärdering av påstådd "säkerhet efter förslutning av slutförvaret”, Bilaga 1, p. 27-44, In: Milkas, Yttrande om SKB AB:s ansökan om tillstånd enligt miljöbalken och kärntekniklagen till anläggningar i ett sammanhängande system för slutförvaring av använt kärnbränsle och kärnavfall, Nacka Tingsrätt, Mark- och miljödomstolens mål M13333-11, 2012 b.

Mörner, N.-A.: Paleoseismic fracturing of rock carvings $1000 \mathrm{BC}$ in SE Sweden, INQUA-IGCP 567 Proceedings, Morelia, Mexico, 3, 127-130, 2012c.

Mörner, N.-A.: Drainage varves, seismites and tsunamites in the Swedish varve chronology, GFF, doi:10.1080/11035897.2013.764546, in press, 2013a.

Mörner, N.-A.: The DRD method: a short presentation - DRD metoden: en kort presentation, P\&G-print, 28 pp., $2013 \mathrm{~b}$.

Mörner, N.-A.: Paleoseismic events during the interstadial around $30000 \mathrm{BP}$, in preparation, 2013c.

Mörner, N.-A. and Dawson, S.: Traces of tsunami events in off- and on-shore environments. Case studies in the Maldives, Scotland and Sweden, in: The Tsunami Threat: Research and Technology, edited by: Mörner, N.-A., InTech Publ. Co, 371-388, 2011.

Mörner, N.-A. and Sjöberg, R.: Excursion Guide, Second International Conference on Granite Caves, Sweden 2011, Svenska Grottor, No. 12, 1-28, 2011.

Mörner, N.-A. and Sun, G.: Paleoearthquake deformations recorded by magnetic variables, Earth Planet. Sc. Lett., 267, 495-502, 2008.

Mörner, N.-A., Tröften, P. E., Sjöberg, R., Grant, D., Dawson, S., Bronge, C., Kvamsdal, O., and Sidén, A.: Deglacial paleoseismicity in Sweden: the 9663 BP Iggesund event, Quaternary Sci. Rev., 19, 1461-1468, 2000.

Olesen, O.: The Stuoragurra Fault; evidence of neotectonics in the Precambrian of Finnmark, northern Norway, Norsk Geol. Tidsskr., 68, 107-118, 1988.

Piccardi, L. and Masse, W. B. (Eds.): Myth and Geology, Geol. Soc. Spec. Publ., 273, 1-350, 2007.

Posiva: Safety Case for the Disposal of Spent Nuclear Fuel at Olkiluoto - Formulation of Radionuclide Release Scenarios, Posiva 2012-08, Posiva Oy, 2012.

Reicherter, K., Michetti, A. M., and Silva Barroso, P. V.: Paleoseismology: historical and prehistorical records of earthquake ground effects for seismic hazard assessment, Geol. Soc. Spec. Publ., 316, 1-10, 2009.

Rockwell, T.: The non-regularity of earthquake recurrence in California: Lessons from long paleoseismic records from the San Andreas and San Jacinto faults in southern California, and the north Anatolian fault in Turkey, Proceeding of Fifth International Conference on Recent Advances in Geotechnical Earthquake Engineering and Soil Dynamics and Symposium in Honor of Professor I.M. Idriss; Paper No. EQ 5, 9 pp., 2010.

Silva, P. G., Sintubin, M., and Reichester, K. (Eds.): Earthquake Archaeology and Palaeseismology, Quatern. Int., 242, 1-253, 2011.

Sintubin, M.: Archaeoseismology: past, present and future, Quatern. Int., 242, 4-10, 2011.

Sjöberg, R.: Bedrock caves and fractured bedrock surfaces in Sweden. Occurrence and origin, Stockholm University, Ph.D. thesis, P\&G 7, 1-110, 1994.

SKB (Svensk Kärnbränslesäkerhet): Redovisning av säkerhet efter förslutning av slutförvaret för använt kärnbränsle, Huvudrapport från project SR-Site, Del I-III, 2011. 
Stephansson, O., Sonnerfelt, L., Bunbgum, H., and Lindholm, C. (Eds.): Workshop on seismology, Strålskyddsmyndigheten, SSM rapport 2012, 25, 1-118, 2012.

Stiros, S. and Jones, R. E. (Eds.): Archaeoseismology, Fitch Lab. Occasional Paper, 7, 1-268, 1996.

STUK: Disposal of nuclear waste. Guide STUK-YVL D.5-L4 (version 17.3.2011). Radiation and Nuclear Safety Authority (STUK), https://ohjeisto.stuk.fi/YVL/D.5-L4.pdf, 2011.
Wang, J.-M.: The Fenwei Rift and its recent periodic activity, Tectonophysics, 133, 257-275, 1987.

Wells, D. L. and Coppersmith, K. J.: New empirical relationships among magnitude, rupture length, rupture width, rupture area and surface displacement, Bulletin Seismological Society of America, 84, 974-1002, 1994. 